\title{
The Enzymatic Microestimation of Free and Combined Adenine in Tissues
}

\author{
By E. Manoukian and G. Fawaz \\ Department of Pharmacology', School of Medicine, American University of Beirut, Bcirut, Lebanon
}

(Eingegangen am 16. Juli 1970)

\begin{abstract}
A micromethod is described for the enzymatic estimation of free and combined adenine in the presence of hypoxanthine and xanthine. It is based on the conversion of adenine to 2:8-dihydroxyadenine by xanthine oxidase, a reaction that is infinitely slower than the action on hypoxanthine or xanthine by the same enzyme.
\end{abstract}

Eine Mikromethode zur enzymatischen Bestimmung von freiem und gebundenem Adenin in Gegenwart von Hypoxanthin und Xanthin wird beschrieben. Sie beruht auf der Umwandlung von Adenin zu 2,8-Dihydroxyadenin, eine Reaktion, die crheblich langsamer ist als die Wirkung des gleichen Enzyms auf Hypoxanthin oder Xanthin.

The enzymatic estimation of hypoxanthine (plus xanthine) is based on the method of KALCKAR (BERGMEYER) (1). Here, hypoxanthine is acted upon by xanthine oxidase changing it to uric acid via xanthine. The uric acid is then estimated by the action of uricase. Adenine is also attacked by xanthine oxidase (from milk) with uptake of $\mathrm{O}_{2}$ but with no liberation of ammonia (BoOTH) (2). BENDICH and coworkers (3) administered adenine to rats and observed deposition of 2:8-dihydroxyadenine in the kidneys, a reaction which they attributed to the action of xanthine oxidase on adenine. Direct evidence of this reaction has been provided by KLENOW (4) who obtained 2:8-dihydroxyadenine, in pure form, by the action of xanthine oxidase (from milk) on adenine in vitro. He determined the extinction coefficient of the product at $\lambda=305 \mathrm{~nm}$ at different $\mathrm{pHs}$, a wavelength that permits the estimation of $2: 8$-dihydroxyadenine in the presence of adenine.

In this paper we describe a method that permits the simultaneous estimation of free and combined adenine and the sum of xanthine plus hypoxanthine, and which we feel is simple and less time-consuming than the presently available chemical and chromatographic methods. This method utilizes the known fact (KLENOw, (4)) that xanthine oxidase changes hypoxanthine or xanthine to uric acid at a vastly higher rate than it oxidizes adenine to 2:8-dihydroxyadenine. In our procedure a small amount of xanthine oxidase is added to the mixture of adenine and hypoxanthine which allows the reaction hypoxanthine $\longrightarrow$ uric acid to go to completion within a few minutes. Addition of more enzyme and a more prolonged exposure is necessary for the reaction adenine $\longrightarrow 2: 8$-dihydroxyadenine to come to an end. Readings every one minute at the onset of the reaction provides the necessary data for extrapolation and thus correction for the almost negligible amount of adenine that reacts during the first few minutes. Combined adenine (ATP, ADP, AMP, adenosine) and combined hypoxanthine (ITP, IDP,
IMP, inosine) have to be converted to the free form before analysis. This can be done merely by heating the perchloric acid tissue extracts to $100^{\circ} \mathrm{C}$ for $30 \mathrm{~min}$., before neutralization with $\mathrm{KOH}$.

The reactions involved are the following:

$$
\begin{array}{r}
\text { Hyypoxanthine }+\mathrm{O}_{2} \frac{\text { xanthine }}{\text { oxidase }} \rightarrow \text { xanthine }+\mathrm{H}_{2} \mathrm{O}_{2} \\
\text { Xanthine }+\mathrm{O}_{2} \frac{\text { xanthine }}{\text { oxidase }} \rightarrow \text { uric acid }+\mathrm{H}_{2} \mathrm{O}_{2}
\end{array}
$$

(c) Uric acid $+\mathrm{O}_{2}+2 \mathrm{H}_{2} \mathrm{O} \stackrel{\text { uricase }}{\longrightarrow}$ allantoin $+\mathrm{H}_{2} \mathrm{O}_{2}$

(d) Adenine $+2 \mathrm{H}_{2} \mathrm{O}+2 \mathrm{O}_{2} \frac{\text { xanthine }}{\text { oxi Jase }} \rightarrow$ 2:8-dihydroxyadenine

$$
\text { 2:8-dihydroxyadenine } \stackrel{\text { uricase }}{\longrightarrow} \text { no reaction }
$$

The increase in optical density after $10 \mathrm{~min}$. at $291 \mathrm{~nm}$ (the maximum point on the extinction curve of uric acid), is a measure of the amounts of hypoxanthine plus xanthine present. Uricase changes uric acid to allantoin which shows no absorbancy at 291 or $304 \mathrm{~nm}$ and thus nullifies the increase in optical density at $291 \mathrm{~nm}$ due to uric acid arising from hypoxanthine or xanthine. The addition of more xanthine oxidase now acts solely on adenine changing it to 2:8-dihydroxyadenine which can be measured by the increase in optical density at $304 \mathrm{~nm}$. Whatever small amounts of 2:8-dihydroxyradenine have been formed from adenine due to the action of xanthine oxidase during the first ten minutes (before the addition of uricase and excess xanthine oxidase) and which interfers with the measurement of uric acid at $291 \mathrm{~nm}$, can be corrected for by extrapolation. The increase in optical density during the second five-minute period is subtracted from that observed during the first fiveminute period and the difference gives the net $\Delta \mathrm{E}$ which is a measure of the amount of hypoxanthine (plus xanthinc) present. A glance at Figure 1 illustrates the significance of these considerations. 


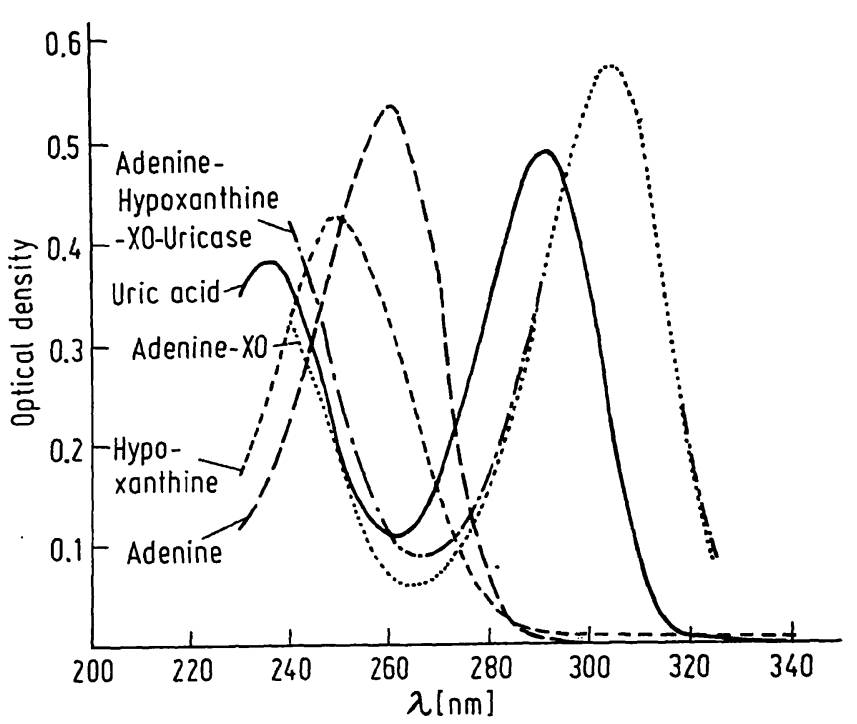

Fig. 1

Absorption spectra of ajenine, hypoxanthine and uric acid and their changes after the action of xanthine oxidase and uricase

\section{Material and Methods}

\section{Enzymes and Reagents}

1. Xanthine oxidase ex milk (Koch-Light Laboratories, Colnbrook, Bucks, England). Suspension in $60 \%$ ammonium sulfate with $0.02 \%$ sodium salycilate, $10 \mathrm{mg}$ protein $=3.4$ urits $/ \mathrm{m} /$. Dilutions of the enzyme are made with $2 \mathrm{M}$ ammonium sulfate.

2. Uricase from hog liver (Koch-Light) 100 Praetorius units per ampoule. The powder is dissolved in $2 \mathrm{ml}$ of borax- $\mathrm{NaOH}$ (12.5 mM as borax) buffer $\mathrm{pH} 9.28$.

3. Sodium phosphate buffer $0.1 \mathrm{M}, \mathrm{pH}=7.4$.

4. Tetracycline $\mathrm{HCl}, 10 \mathrm{mg}$ per liter of phosphate buffer.

\section{Procedure}

Tissue samples are frozen in liquid air, powdered and deproteinized with $0.65 \mathrm{~N}$ perchloric acid $(9.2 \mathrm{ml}$ acid/g tissue to give a $1: 10$ dilution) as described previously (FAwAz and coworkers (5)). Let stand for $10 \mathrm{~min}$. at $0^{\circ} \mathrm{C}$ with occasional shaking and centrifuge. A sample $(4 \mathrm{~m} l)$ of the supernatant is pipetted into a $5 \mathrm{~m} l$ pyrex volumetric flask and the latter immersed in boiling water for $30 \mathrm{~min}$. Cool, make up to volume with distilled water. An aliquot sample $(4 \mathrm{ml})$ is taken and neutralized with $15 \% \mathrm{KOH}$ using phenolphthalein as indicator. Let stand for $20 \mathrm{~min}$. and centrifuge. The supernatant is used for the estimation of adenine and the sum of hypoxanthine and xanthine.

The reagents are pipetted into a quartz cuvette (Hellma, light path $1 \mathrm{~cm}$, capacity $3 \mathrm{ml}$ ) of a Zeiss PMQII u. v. spectrophotometer or an equivalent instrument in the following order:

$1.0 \mathrm{~m} /$ phosphate buffer containing $10 \mathrm{mg}$ tetracycline $\cdot \mathrm{HCl}$ per liter.

$0.05-0.2 \mathrm{~m} i$ sample of tissue extract.

Water containing tetracycline $(10 \mathrm{mg} / \mathrm{l})$ up to a volume of $1.84 \mathrm{ml}$.

Stir thoroughly and take readings at 304 and $291 \mathrm{~nm}$ every five minutes until the optical density stays constant. Add xanthine oxidase suspension $20 \mu l$ (or an amount sufficient to complete the reaction in five $\mathrm{min}$.) containing 1.55 units $/ \mathrm{m} /$. Readings are taken every minute for 10 minutes at $291 \mathrm{~nm}$. Add $100 \mu /$ more of the xanthine oxidase and $40 \mu l$ uricase (50 Praetorius units $/ \mathrm{ml}$ ). Take an initial reading at $304 \mathrm{~nm}$ and leave ovcrnight at room tempcrature. The next morning take readings at hourly intervals until the optical density remains steady for three consecutive readings.

The blank cuvette contains $1 \mathrm{~m} /$ of the buffer, $0.84 \mathrm{~m} / \mathrm{H}_{2} \mathrm{O}$ (both solutions containing tetracycline) and all the enzymes added at the same time as to the reagent curette.

\section{Calculations}

The extinction coefficient of 2:8-dihydroxyadenine prepared enzymatically from adenine was found to be $14.54 \mathrm{~cm}^{2} / \mu$ mole at a wavelength of $304 \mathrm{~nm}$ and that of uric acid $12.0 \mathrm{~cm}^{2} / \mu$ mole at $291 \mathrm{~nm}$. Example: A rat gastrocnemius was isolated and incubated at $37^{\circ} \mathrm{C}$ for 3 hours. $4 \mathrm{~m} l$ of the perchloric acid extract were hydrolyzed for $30 \mathrm{~min}$. at $100^{\circ} \mathrm{C}$ and the volume made up to $5 \mathrm{ml}$ after cooling. $2 \mathrm{ml}$ of this solution were neutralized with $0.46 \mathrm{~m} / \mathrm{KOH}$. Sample $=0.1 \mathrm{~m} l$, net $\Delta \mathrm{E}$ for xanthine-hypoxánthine $=0.288$ (after subtracting the increase in optical density during the second five minutes from that observed during the fitst five minutes), $\Delta \mathrm{E}$ for adenine $=0.062$.

Xanthine-hypoxanthine $=\frac{0.288}{12} \times 1.86 \times 10 \times \frac{2.46}{2}$ $\times \frac{5}{4} \times 10=6.86 \mu$ moles per $\mathrm{g}$ wet tissue Adenine $=\frac{0.062}{14.54} \times 2 \times 10 \times \frac{2.46}{2} \times \frac{5}{4} \times 10=1.31 \mu$ moles

1.86 and 2 are the volumes of the reaction mixtures, the difference in volume for the adenine estimation being due to the addition of $0.04 \mathrm{~m} l$ uricase and $0.1 \mathrm{~m} l$ xanthine oxidase.

\section{Results and Discussion}

Adenine exists in fresh or ischemic skeletal muscle in the form of ATP, ADP and AMP. (Adenine and adenosine are not found in measurable quantities (DEUTICKE and coworkers (6)). Accurate enzymatic methods for the estimation of these three nucleotides are in existence (BERGMEYER (1)), (E. N. FAWAZ and G. FAWAZ (7)), (E. N. FawaZ and G. FAwaZ (8)).

A comparison of the results obtained by the method described above for free adenine after hydrolysis of the nucleotides with those obtained by the classical enzymatic methods for the nucleotides showed good agreement, not only when the adenine content is high but also in ischemic muscle after incubation at $37^{\circ} \mathrm{C}$ for three hours, when the adenine content is low.

This is illustrated in Table 1 where in each case a sample of dog skeletal muscle was analyzed before and after a 3 hours period of ischemia.

Samples of pure ATP, ADP, AMP and adenosine were hydrolyzed in $0.5 \mathrm{~N}$ perchloric acid for $30 \mathrm{~min}$. at $100^{\circ} \mathrm{C}$ and the free adenine analyzed as described above. The same was done for samples of inosinic acid and inosine. In all cases, satisfactory values were obtained showing that thirty minutes of hydrolysis are sufficient to liberate the free purines from the nucleotides and nucleosides. Furthermore, tecovery studies were performed by adding free adenine and hypoxanthine to samples of perchloric acid tissue extracts before and after neutralization with $\mathrm{KOH}$. The recoveries were within the experimental errors reported in Table 1.

The errors are due not to the method itself but to the measuring devices such as pipettes and spectrophotometers. It must be remembered that not only samples of tissue extracts must be measured accurately but also samples of the enzymes which also happen to absorb at the wavelengths 291 and $304 \mathrm{~nm}$. For instance, it is 
Tab. 1

Comparison of the values for total adenine obtained by direct enzymatic analysis of adenine nucleotides with those obtained by analyzing free adenine after hydrolysis utilizing the xanthine oxidase method. The figures indicate micromoles per $g$ wet tissue

\begin{tabular}{|c|c|c|c|c|c|c|}
\hline & & $\begin{array}{c}\text { ATP } \\
{[\mu \mathrm{Mol} / \mathrm{g}]}\end{array}$ & $\begin{array}{c}\text { ADP } \\
{[\mu \mathrm{Mol} / \mathrm{g}]}\end{array}$ & $\begin{array}{c}\text { AMP } \\
{[\mu \mathrm{Mol} / \mathrm{g}]}\end{array}$ & $\begin{array}{c}\text { Total } \\
\text { adenine } \\
{[\mu \mathrm{Mol} / \mathrm{g}]}\end{array}$ & $\begin{array}{c}\text { Free adenine } \\
\text { after hydrolysis } \\
{[\mu \mathrm{Mol} / \mathrm{g}]}\end{array}$ \\
\hline Dog 1 & $\begin{array}{l}\text { Fresh muscle } \\
\text { Ischemic muscle }\end{array}$ & $\begin{array}{l}5.63 \\
0.16\end{array}$ & $\begin{array}{l}0.82 \\
0.49\end{array}$ & $\begin{array}{l}0.22 \\
0.08\end{array}$ & $\begin{array}{l}6.67 \\
0.73\end{array}$ & $\begin{array}{l}6.50 \\
0.75\end{array}$ \\
\hline $\operatorname{Dog} 2$ & $\begin{array}{l}\text { Fresh muscle } \\
\text { Ischemic muscle }\end{array}$ & $\begin{array}{l}6.53 \\
0.22\end{array}$ & $\begin{array}{l}0.93 \\
0.55\end{array}$ & $\begin{array}{l}0.08 \\
0.05\end{array}$ & $\begin{array}{l}7.54 \\
0.82\end{array}$ & $\begin{array}{l}7.31 \\
0.73\end{array}$ \\
\hline $\operatorname{Dog} 3$ & $\begin{array}{l}\text { Fresh muscle } \\
\text { Ischemic muscle }\end{array}$ & $\begin{array}{l}5.52 \\
1.17\end{array}$ & $\begin{array}{l}1.00 \\
0.89\end{array}$ & $\begin{array}{l}0.03 \\
0.06\end{array}$ & $\begin{array}{l}6.55 \\
2.12\end{array}$ & $\begin{array}{l}6.51 \\
2.11\end{array}$ \\
\hline Dog 4 & $\begin{array}{l}\text { Fresh muscle } \\
\text { Ischemic muscle }\end{array}$ & $\begin{array}{l}5.92 \\
0.25\end{array}$ & $\begin{array}{l}0.86 \\
0.18\end{array}$ & $\begin{array}{l}0.12 \\
0.22\end{array}$ & $\begin{array}{l}6.90 \\
0.65\end{array}$ & $\begin{array}{l}6.60 \\
0.60\end{array}$ \\
\hline Dog 5 & $\begin{array}{l}\text { Fresh muscle } \\
\text { Ischemic muscle }\end{array}$ & $\begin{array}{l}5.73 \\
0.50\end{array}$ & $\begin{array}{l}0.75 \\
0.31\end{array}$ & $\begin{array}{l}0.06 \\
0.13\end{array}$ & $\begin{array}{l}6.54 \\
0.94\end{array}$ & $\begin{array}{l}6.49 \\
1.07\end{array}$ \\
\hline
\end{tabular}

not possible to measure $20 \mu l$ of an enzyme solution without incurring an error of $3-5 \%$. The tetracycline added also absorbs at this wavelength and accuracy should be exercised in measuring its solutions. Actually, it is possible to omit the tetracycline if sterile solutions are employed to begin with.
Guanine and uracil do not react with xanthine oxidase.

\section{Acknowledgement}

This work was supported by a research grant from the Research Committce of the School of Medicine, American University of Beirut.

\section{References}

1. Bergmeyer, H. U., Methods of enzymatic analysis, Chapter 5, Verlag Chemie, Weinheim/Bergstr. (1963). - 2. BoorH, V. H., Biochem. J. 32, 494 (1938). - 3. BeNdrch, A., G. B. Brown, F. S. Philips and J. B. Thierșch, J. biol. Chemistry 183, 267 (1950). - 4. Klenow, H., Biochem. J. 50,404 (1952). - 5. Fawaz, E. N., G. Fawaz and K. v. Dahl, Proc. Soc. exp. Biol. (N. Y.) 109,
38 (1962). - 6. Deuticke, B., E. GerLach and R. DierkesmanN, Pflügers Archiv Physiol. 292, 239 (1966). - 9. Fawaz, E. N., and G. FAwAZ, Biochem. J. 83, 438 (1962). - 8. FawAz, E. N., and G. FAwaz, Phosphate Compound Analysis in Schwartz: Methods in Pharmacology, Chaptex 17, Appleton - Century - Crofts, 1970 (in press).
Prof. Dr. George Fawaz Dept. of Pharmacology School of Medicine American University of Beirut Beirut, Lebanon 